\title{
Root and stem rot caused by Pythium aphanidermatum on poinsettia in a soil-less culture system in Buenos Aires Province, Argentina
}

\author{
H. E. Palmucci ${ }^{\mathrm{A}, \mathrm{B}}$ and P. E. Grijalba ${ }^{\mathrm{A}}$ \\ A Facultad de Agronomía de la Universidad Nacional de Buenos Aires, Avenida San Martín 4453, \\ (1416) Buenos Aires, Argentina. \\ ${ }^{\mathrm{B}}$ Corresponding author. Email: palmucci@agro.uba.ar
}

\begin{abstract}
Root and stem rot of rooted cuttings of young poinsettia plants were observed in a soil-less culture system in Buenos Aires Province, Argentina. Pythium aphanidermatum was identified as the causal agent of these symptoms. This is the first report of $P$. aphanidermatum affecting poinsettia in Argentina.
\end{abstract}

The use of soil-less cultures compared with traditional culture systems is considered to be an alternative production method that makes better use of water and nutrients. From the 1980 s to 2001 the worldwide area with soilless culture production has increased four to five times (http://www.rirdc.gov.au/reports/Ras/01-141.pdf, verified 10 September 2007). The dissemination of diseases in these systems favours waterborne pathogens. The transition from traditional cultivation methods to these soil-less cultures requires knowledge of the pathogens involved in the latter. For this reason in 2003 and 2004 a survey was conducted by Buenos Aires University in ornamental nurseries in the vicinity of Buenos Aires. Several disease symptoms were observed on rooted cuttings or young plants of poinsettia (Euphorbia pulcherrima) 'Freedom Red', developed in Oasis ${ }^{\circledR}$ (www.oasisgrower.co.nz, verified 10 September 2007) growing medium or in organic substrate (pine leaf, river organic sediment, earth $(2: 1: 1)$ or $5 \%(\mathrm{v} / \mathrm{v})$ of peel rice) (Fig. 1). The culture was developed in a glasshouse with lateral and central ventilation and the cuttings had been placed on benches with an inclination of $5 \%$ to enable the draining of nutrient solution $(100 \mathrm{mg} / \mathrm{L}$ of $\mathrm{N}$ with a balanced solution of NPK fertiliser $(15: 10: 15)$, and micronutrients. Irrigation and fertilisation were performed using perforated tubes installed on the substrate between rows of plants.

These plants showed stem rot and wilting. The disease extended up into the base of the stem and the cuttings usually died in a few days. When the plants were removed from the substrate a dark brown to black wet rot was observed on roots which were soft and disintegrated when touched. Oospores of Pythium sp. were detected in microscopic preparations of the cortical cells on the roots.

Small pieces $(3-4 \mathrm{~mm})$ of affected tissue were surface disinfected by immersion in $2 \%$ sodium hypochlorite for $2 \mathrm{~min}$., rinsed twice in distilled water, and then placed on V8 agar and potato dextrose agar (PDA) in Petri plates, which were

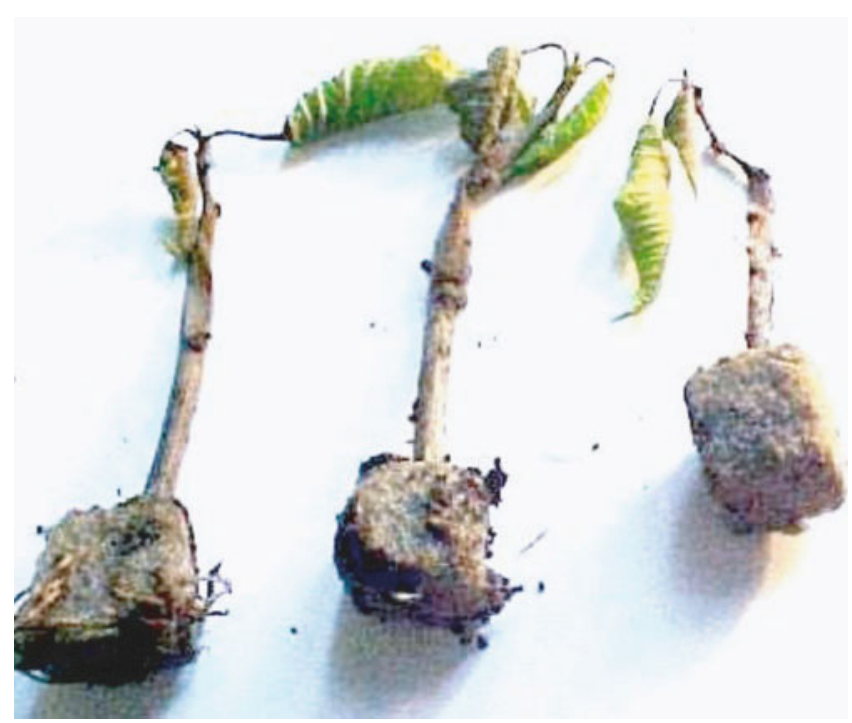

Fig. 1. Poinsettia cutting growing in Oasis foam, showing symptoms typical of infection by $P$. aphanidermatum.

incubated at $22^{\circ} \mathrm{C}$ for $48 \mathrm{~h}$ in the dark. The formation of sporangia and zoospores were induced by placing sections of 1-2 cm autoclaved Agrostis leaves in the plate colony (grassbaiting method) (Abad et al. 1994).

Pathogenicity tests were carried out on 10 healthy plants (variety 'Freedom Red') from micropropagation. Three or four $20 \mathrm{~mm}$ long plugs of mycelium were removed from a 10day-old Petri plate culture and placed below the collar of these plants previously wounded with a sterile needle. Control plants were inoculated with agar discs that did not contain the fungus. All plants were kept in wet plastic bags (near $100 \%$ relative humidity) at $22 \pm 2^{\circ} \mathrm{C}$ for $48 \mathrm{~h}$ and then maintained in a glasshouse. Three days after inoculation, symptoms similar 
to the original were observed on the inoculated plants. Control plants remained symptomless. Koch's postulates were confirmed by reisolating the same fungus from diseased plants.

The isolated fungus was characterised after 10 days. Cultures on PDA and V8 quickly formed a fluffy, cottony growth, which showed radial patterned mycelium with coenocytic hyaline hyphae. All isolates showed the same growth and morphological characteristics: homothallic, lobate (inflated) (Fig. 2) or filamentous sporangia, one antheridium $(8.8-10 \mu \mathrm{m}$ wide by $10.9-14.1 \mu \mathrm{m}$ long) per oogonium (Fig. 3) often intercalary, oogonia terminal $17.9-27.4 \mu \mathrm{m}$ (av. $22.6 \mu \mathrm{m}$ ) in diameter, oospores aplerotic $14.75-21.30 \mu \mathrm{m}(\mathrm{av} .18 .0 \mu \mathrm{m})$ in diameter.

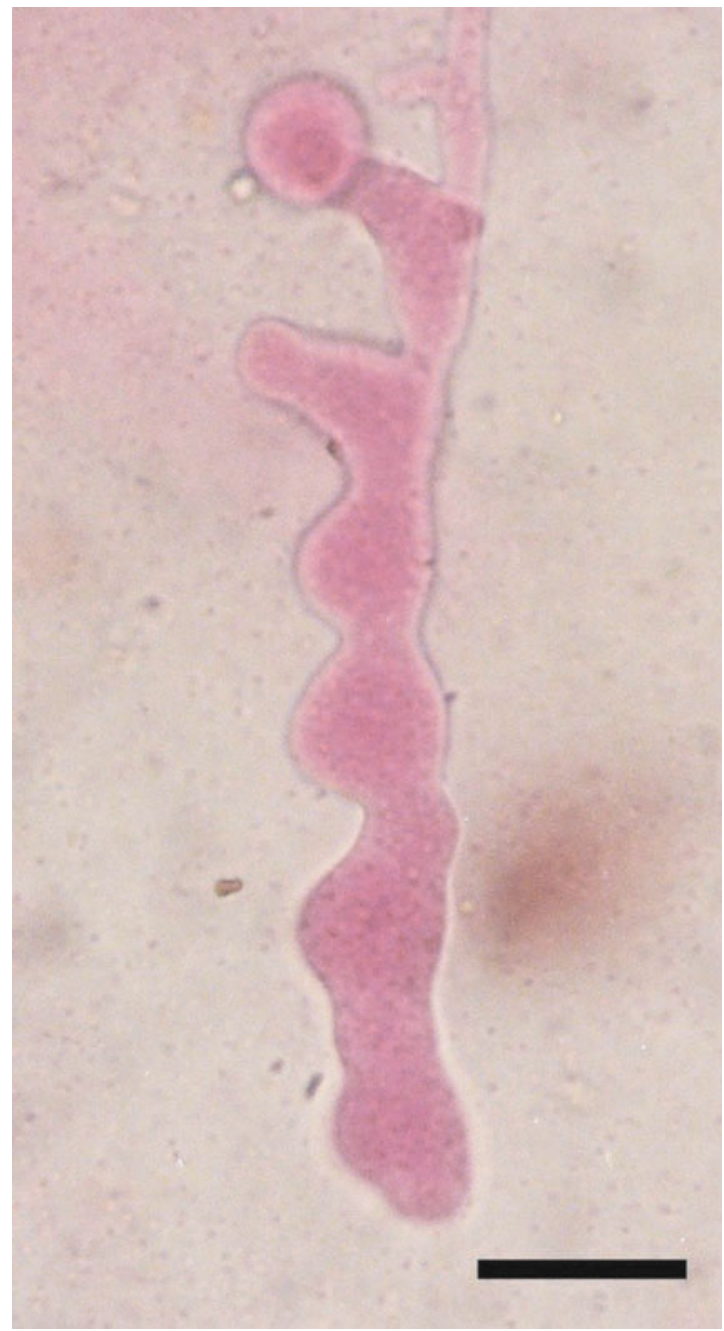

Fig. 2. Inflated sporangium of $P$. aphanidermatum. $\mathrm{Bar}=20 \mu \mathrm{m}$.

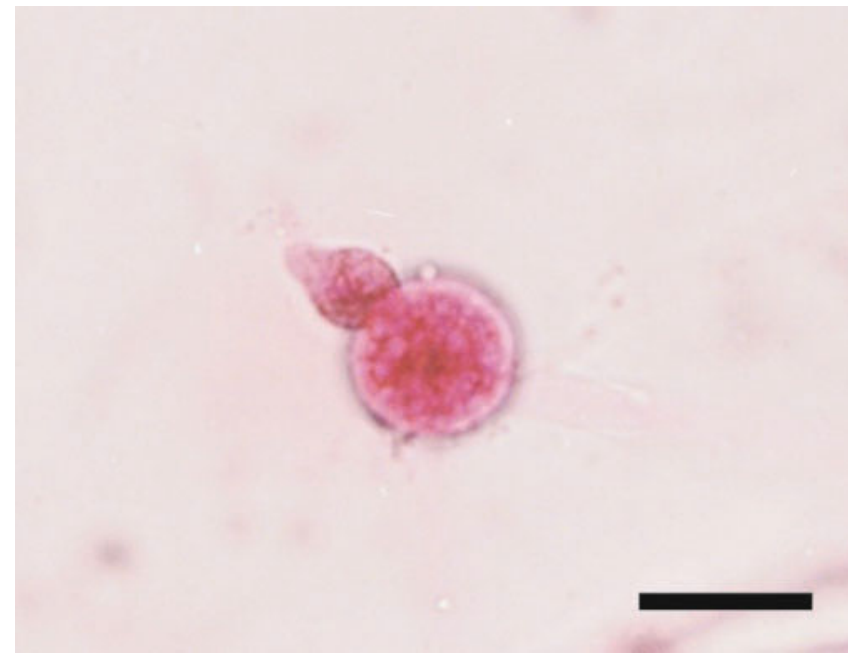

Fig. 3. Antheridia and oogonia of $P$. aphanidermatum. Bar $=20 \mu \mathrm{m}$.

In accordance with morphological biometrics and cultural characteristics, the pathogen was identified as Pythium aphanidermatum (Frezzi 1956; Dick 1990). This is the first report of this fungus causing root rot and stem rot on Poinsettia in Buenos Aires, Argentina. In Argentina this fungus was first isolated from Pisum sativum in 1950 and then recorded in many other plants. In 1953 it was reported on adult plants of Euphorbia marginata in Córdoba Argentina which caused death due to root destruction (Frezzi 1956). In Poinsettia, P. ultimum, $P$. aphanidermatum, $P$. splendens are recorded as pathogens (Daughtrey et al. 1995). This water mould pathogen produces zoospores that can swim short distances in the water or nutritional solution (fertigation) and survive with oospores. This may be the major problem of the soil-less system cultures in Argentina and for that reason it is necessary to disinfect the lixivia nutrition solution before re-using it.

\section{References}

Abad ZG, Shew HD, Lucas LT (1994) Characterization and pathogenicity of Pythium species isolated from turfgrass with symptoms of roots and crown rot in North Carolina. Phytopathology 84, 913-921. doi: 10.1094/Phyto-84-913

Daughtrey ML, Wick RL, Peterson JL (1995) 'Compendium of flowering potted plant diseases.' (APS Press: St Paul, MN)

Dick MW (1990) 'Keys to Pythium.' (College of Estate Management, Whiteknights: Reading)

Frezzi MJ (1956) Especies de Pythium fitopatógenas identificadas en la República Argentina. Revista de Investigaciones Agrícolas. Tomo X, Número 2, Buenos Aires, Argentina.

Manuscript received 1 May 2007, accepted 6 September 2007 